\title{
"This Virus is a Common Threat to All Humans": Discourse Representation of COVID-19 in Selected Newspaper Editorials
}

\author{
By Ayo Osisanwo*
}

\begin{abstract}
Existing studies on viruses with bias for COVID-19 have mainly been carried out from non-linguistic fields. Linguistics-related studies have not examined the media representation of COVID-19 since it is a recent development. This study, therefore, identifies the representational strategies, discourse structures and discourse strategies deployed by selected newspapers in representing COVID19 and associated participants. Data were retrieved from selected COVID-19related editorials from four purposively selected countries and continents across the world: New York Times (USA, North America), The Guardian (UK, Europe), China Daily (China, Asia) and The Punch (Nigeria, Africa), published in the early periods of the pandemic, and precisely from January 1 - March 31, 2020. Guided by aspects of van Dijk's socio-cognitive model of critical discourse analysis on ideological discourse structures, data were quantitatively and qualitatively analysed. The newspaper editorials unusually converged to negatively represent an issue - COVID-19 - because it is largely negatively viewed by all. Ten representational strategies (like economic cankerworm, threat to humans, common enemy), six discourse strategies (like demonising, criminalising, condemnation) and twelve ideological discourse structures (like Actor Description, Authority, Burden) and different participant representations and roles (like solver, potential super spreader) were identified in the study. The newspapers largely set the agenda on the negative representation of the virus and its potential havoc on all facets of human endeavours, thereby giving emotional and informational appeal to all to join hands in earnestly silencing the epidemic.
\end{abstract}

Keywords: COVID-19, media representation, newspaper editorials, discourse strategies, discourse structures

\section{Introduction}

The novel coronavirus (otherwise known as COVID-19), which is an acute respiratory disease, allegedly evolved in Wuhan China in December 2019. The first official report of the virus was made on December 8, 2019. The virus has rapidly spread from a single city of Wuhan to other parts of China within a short time and has since become a global pandemic. This has not only attracted attention all over the world, but has equally hampered a lot of activities all over the world. In fact, the World Health Organization (WHO), on 30 January 2020, officially declared the COVID-19 epidemic as a public health emergency of international

\footnotetext{
*Lecturer, University of Ibadan, Nigeria.
} 
concern. As at 12noon on April 19, 2020 the number of recorded cases of COVID19 had risen to 2,347,777; the number of deaths was put at 161,126; the number of recovered and discharged cases was 605,661; while 1,580,990 were the outstanding active cases (worldometres.info/coronavirus). The WHO (2020) has described coronavirus (COVID-19) as an infectious disease caused by a newly discovered novel coronavirus, and most people infected with the COVID-19 virus often experience mild to moderate respiratory illness and recover without requiring special treatment. Meanwhile, older people, and those with underlying medical problems like cardiovascular disease, diabetes, chronic respiratory disease, and cancer are more likely to develop serious illness. The WHO warned that the best way to prevent and slow down its transmission is for all to be well-informed about the COVID-19 virus, the disease it causes and how it spreads ${ }^{1}$. The WHO has further confirmed that the COVID-19 virus spreads primarily through droplets of saliva or discharge from the nose when an infected person coughs or sneezes; and further advised that since there is no known vaccines or treatments for COVID-19 yet, human beings across the world must practise respiratory etiquette (for example, by coughing into a flexed elbow or tissue).

Compared with other illnesses such as influenza, SARS, Ebola and so forth, COVID-19 has been presumed as (one of) the major killer-diseases across the world in 2020. COVID-19 is a major, if not the most, cause of human mortality in 2020. Arguably, it has had the highest fatality rate among known viruses in 2020. Different ailing conditions have had encounters with the human race at different times. A hundred and two years ago, that is, in the year 1918, there was the influenza pandemic that ravaged the globe. Potter (2001) reports that 50 percent of the world's population was infected during the 1918 pandemic, while the total mortality was between 40 and 50 million out of a world population of 1.8 billion then (Barry, 2005). Hence, the fatality rate was 5.6 percent. Similarly, seventeen years ago, that is, in the year 2003, there was the outbreak of severe acute respiratory syndrome (SARS). According to the WHO, 8098 people worldwide contracted SARS during the 2003 outbreak, out of which 774 died, making the SARS fatality rate 9.6 percent. Comparing the two, the WHO remarked that the death toll percentage of 9.6 percent from SARS was far higher than that of the 5.6 percent of the 1918 influenza pandemic. With the data supplied earlier, the fatality rate of the current COVID-19 has reached almost seven percent.

The Economist on April 7 confirmed the deadly nature of the coronavirus thus: "The novel coronavirus has killed tens of thousands of people around the world since it first emerged in China last December.... It is a choice between life, death and economy!"2 No doubt, the level of fear in the world has been documented by the London Economist, as there is palpitation in the world with the current COVID-19 outbreak. Already, it is the first severe infectious disease that emerged and attracted so many victims within a very short time in the 21 st Century.

COVID-19 is a very sensitive matter; its sensitivity and outbreak has made it a foremost matter and most reported issue in all tabloids across the world in 2020. The attention given to COVID-19 has suppressed some other events happening

\footnotetext{
${ }^{1}$ https://www.who.int/health-topics/coronavirus\#tab=tab_1.

${ }^{2}$ https://www.economist.com/topics/london-1
} 
concurrently more so that the world seems to have been in a standstill combatting the coronavirus. Media constitute one of the main means through which text consumers get to know more about coronavirus and its escapades. Hence, news producers sit at a vantage position of orienting the readers. No doubt, media outlets have equally risen up to the occasion to give the virus a wide publicity and reportage across the world. Hence, COVID-19 has been the subject of continuous widespread media coverage, especially since the beginning of 2020 .

Existing works on media discourse have focused on how selected persons, groups or issues are represented based on their religious, social or political inclinations, while others have been based on their tribal proclivity or ideological stance (Majid, 2008; Mahdi, 2009; Talaat, 2011; Osisanwo, 2011, 2016a, 2016b, 2017a, 2017b, 2019; Oyeleye and Osisanwo, 2013a, 2013b; Chiluwa and Odebunmi, 2016; Osisanwo and Oluwayemi, 2018). Such studies have examined how the media have represented actors and their actions in these events. However, the newness of coronavirus which generated an uproar and alarm across the globe has denied it consideration in the academia. Some of the existing works on COVID-19 are works from the sciences. The science-related studies have explored the epidemiology, causes, clinical manifestation, diagnosis, prevention and control of the novel coronavirus. However, studies exploring the linguistic intervention have not emerged. Studies in this domain, like the current one, are urgently needed to contribute their linguistic and discourse interventions to combatting the outbreak of COVID-19. Linguists have not examined COVID-19 in relation to rhetoric, media representation and so forth. Meanwhile, existing linguistic studies (e.g., Eagleton, 2004; Washer, 2004; Chen, 2005; Larson et al., 2005; Wallis and Neriich, 2005; Baehr, 2006; Chiang and Duann, 2007; Trčková, 2015) or virusrelated studies have only considered the representation of related aliments like Influenza, SARS, Ebola. This paper therefore focuses on the discourse representation of coronavirus in the contents of the editorials of major newspapers selected across four countries from four continents across the world. What sort of representations have the newspapers used to form the readers' opinions on coronavirus?

\section{Theoretic Orientation}

Critical Discourse Analysis (CDA) is the study of opaque relationships of causality and determination between discursive practices, events and texts, and wider social and cultural structures, relations and processes (Fairclough 1995; Wodak 2002). CDA is a special form of social cognition shared by social groups which forms the basis of their social representations and practices including their discourse (van Dijk, 2001a). The socio-cognitive approach to CDA links language practice to social cognition. This approach focuses on the fundamental importance of intuition and society in critical analysis of discourse. The socio-cognitive approach of van Dijk incorporates what van Dijk calls mental models. A mental model is a subjective representation of specific events covered in discourse and it represents the personal Episodic Memory of individuals because it can be identified with people's experience (van Dijk 2001a, 2006a). Though mental 
models are personal, they also "involve the instantiation of general, socially shared knowledge or beliefs" (van Dijk, 2006b, p. 367), and signify the necessary interface between the personal and the social, between discourse and society. The mental models describe and explain "how social structures influence and are affected by discourse structures" (van Dijk, 2001b, p. 112). Discourse and social structure are mediated by social cognition. In essence, the human mind is a very significant dimension in the socio-cognitive approach. The capability of the socio-cognitive model of CDA to account for the diverse nature of the language use in media representations favours it for this study. To understand media discourse, there is need to examine the underlying media cognition of the represented participants in news reports and editorials. Such discourse is not only social in orientation but also embodies individual and non-individual characters who are assigned different roles in the representations.

Out of the hundreds of possible categories, van Dijk (2006c, pp. 735-739) introduces 27 categories of ideological discourse structures which include actor description, authority, burden (Topos), categorisation, comparison, consensus, counterfactuals, disclaimer, euphemism, evidentiality, example/illustration, generalisation, hyperbole, implication, irony, lexicalisation, metaphor, selfglorification, norm expression, number game, polarisation, Us-Them, populism, presupposition, vagueness, victimisation, dramatisation and polarisation. According to van Dijk the ideological discourse often features the following overall strategies of what might be called the ideological square: emphasise our good things, emphasise their bad things, de-emphasise our bad things, de-emphasise their good things. However, the manners in which such ideologies are "expressed and especially persuasively conveyed may of course also involve many formal aspects of grammar, discourse and conversation". Meanwhile, we have found twelve of the twenty-seven useful for the purpose of this paper. They include Actor description, which has to do with the way in which actors or members of a particular society are described either in a negative or positive way; Authority, which has to do with mentioning authorities to support one's case; Burden, which has to do with the use of standard argument as sufficient reasons to accept the conclusion; comparison, which has to do with comparing ingroups and outgroups; evidentiality, which involves the use of some evidence or proof to support one's knowledge or opinion; Example/Illustration, which involves using concrete examples in form of short stories to illustrate or make a general point more credible; generalisation, which has to do with using generalisations instead of giving concrete stories; lexicalisation, which involves using specific lexical items to express underlying concepts and beliefs; metaphor, which is the use of imaginative and powerful words and expressions to describe; negative otherpresentation, which involves classifying outgroups as bad; norm expression, which involves giving norm statement about what "we" should and should not do; Number game, which has to do with the use of numbers and statistics to appear credible. Therefore, the identified twelve ideological discourse structures of the socio-cognitive approach will be applied to this study because they are capable of accounting for implicit information that forms writers' mental models. The related aspects of this socio-cognitive model are represented on Figure 1. 
Figure 1. Media Representation of COVID-19

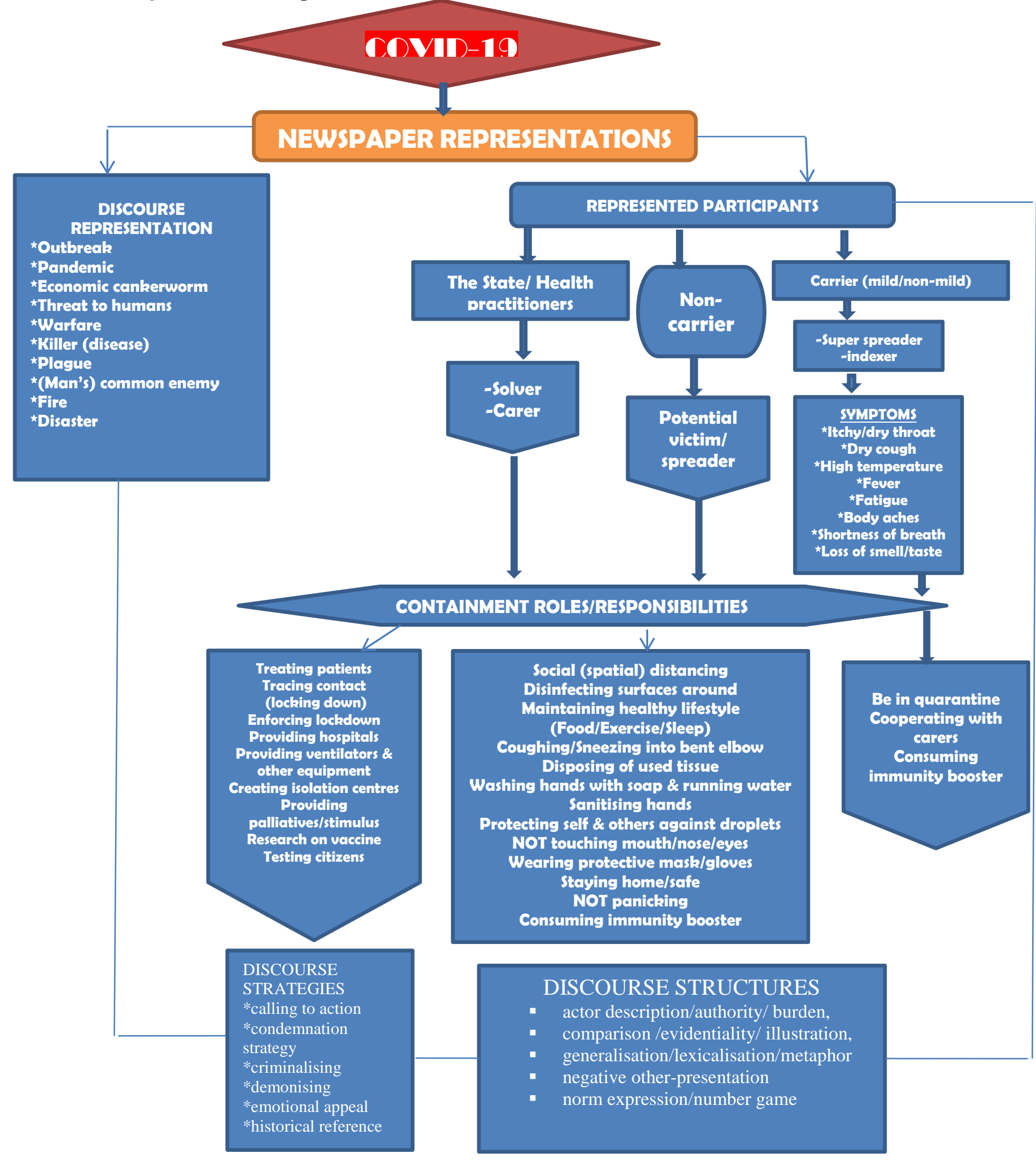




\section{Methods}

For data, editorials on coronavirus from four purposively selected newspapers from four countries and four continents across the world were purposively selected. The selected newspapers are papers rated within the top 200 newspapers in the world (4imn.com Newspaper Web Ranking). They include New York Times (USA, North America), The Guardian (UK, Europe), China Daily (China, Asia) and The Punch (Nigeria, Africa). The selected editorials on coronavirus-related issues are those published in the early periods of the pandemic, and precisely from January 1 - March 31, 2020. The online versions of the papers were assessed. From the 364 newspapers published during the selected period, that is 91 publications per newspaper, the editorials that were strictly written on coronavirus were retrieved thus: New York Times (12 editions), The Guardian (18 editions), China Daily (12 editions) and The Punch (5 editions). The articles were critically read and the aspects that relate to discourse representations of coronavirus were culled out for quantitative and qualitative analyses - with more emphasis on content-anddiscourse.

\section{Analysis and Findings}

As presented on Figure 1, which is the summary of the findings on media representation of COVID-19, ten representations are identified in the sampled newspaper editorials. The representations are COVID-19 as outbreak, pandemic, economic cankerworm, threat to humans, war, killer (disease), plague, common enemy, fire and disaster. In addition, six discourse strategies: demonising the disease, criminalising the disease, calling the state to action, emotional and informational appeal to the masses, condemnation of the state, and historical reference; twelve ideological discourse structures: actor description, authority, burden, comparison, evidentiality, illustration, generalisation, lexicalisation, metaphor, negative other-presentation, norm expression, and number game; and different participant representations and roles: solver, (potential super) spreader, and so forth, were identified in the study. Figure 2 presents the percentage of dominance of the representations. I now discuss the discourse representations and other parts of the analysis.

Figure 2. Discourse Representation of COVID-19 (in Percentages)






\section{Representations}

The newspaper editorials unite to index COVID-19 as a negative phenomenon. Hence, a major representation generated to cut across all representations is the negative portrayal of COVID-19. All the identified ten representations are subsumed under the negative representation of the virus.

\section{Outbreak}

Representation of COVID-19 as outbreak is the most dominant (26\%) representation in our data corpus. The newspaper editorials converge to represent COVID-19 as outbreak - a sudden rise in the incidence of a disease. The reason for the convergent representation is not far-fetched since COVID-19 or coronavirus has been largely described as a condition that has brought about a sudden increase in the number of carriers across the world. Texts 1 to 3 exemplify the deployment.

(1) Lombardy, a sophisticated region in the north with a good health care system, was quickly overwhelmed by its coronavirus outbreak (NYT, March 12, 2020).

(2) Data shows that the UK's coronavirus outbreak is following a similar trajectory to Italy's, with around a two-week delay (The Guardian, March 22, 2020).

(3) In the wake of the outbreak of the virus in China, the country received heartwarming support of various kinds from many countries and a number of international and regional organizations, which consolidated the Chinese people's confidence that they would be able to overcome the virus (China Daily, March 30, 2020).

In texts $1-3$, the editorials of the sampled papers deploy such discourse structures as lexicalisation, burden, illustration, evidentiality to support the representation of COVID-19 as an outbreak. The lexicalisation of this representation implicates the virus as an epidemic eruption that necessitates exigent attention. In addition, the premodification of the word "outbreak" in the expression "coronavirus outbreak" underscores possession, and implicates COVID-19 as the agent behind the outbreak. The expression, "outbreak of the virus in China" equally nominalises the outbreak in point as the COVID-19 virus, and further implicates China as the source of the virus. The rendition of the editorial in text 1 deploys Burden to incriminate COVID-19 as a dastardly outbreak which was able to render helpless a region that had sophisticated health care system, that is, Lombardy, Italy. This argument, adduces the Lombardy experience as the need to accept the conclusion that COVID-19 is an epidemic or outbreak, and sufficiently underscores the need for the state in conjunction with the health-workers to immediately collaborate to picket the outbreak before it goes out of control. 


\section{Pandemic}

The newspaper editorials represent COVID-19 as a pandemic - a disease that spreads over a whole country or the whole world. This representation, accounting for $22 \%$ of the total representations is exemplified in texts 4-6.

(4) Scientists from the Johns Hopkins Center for Health Security estimate that the coronavirus pandemic could necessitate anywhere from 200,000 to 2.9 million I.C.U. visits, and ultimately require some 67,000 I.C.U. beds (NYT, March 12, 2020).

(5) It now appears almost inevitable that the new coronavirus outbreak will soon be identified as a global pandemic (The Guardian, March 18, 2020).

(6) FOR Nigeria, which has just recorded its first novel coronavirus death, the tragic footprints of the global pandemic have become inescapable (The Punch, March 24, 2020).

The preponderant use of "pandemic" to describe COVID-19 in the editorials is motivated by the subsisting experience from the disease. The newspapers converge to implicate that the virus is a pandemic, post-modifying the virus in "coronavirus pandemic" (text 4), and nominalising the virus in "a global pandemic" (text 5) and "the global pandemic" (text 6). In text 4, the editor deploys the use of Authority (Argumentation) and Evidentiality, citing Scientists from the Johns Hopkins Center for Health Security and the estimated figures to support his case and authenticate the evil effect of COVID-19 as a pandemic that requires all attention to mitigate the projected negative impact. Both texts 5 and 6 deploy the use of Actor Description to designate coronavirus. The word "pandemic" has to do with a disease that spreads over a whole country, in the first instance, and if not properly managed, could spread globally. The point in The Guardian's editorial in text 5 "the new coronavirus outbreak will soon be identified as a global pandemic" accentuates the growth in the spread of the virus. The representation incriminates the states and world leaders as not doing enough to combat the virus. COVID-19 is further given a negative representation in text 6 "the tragic footprints of the global pandemic have become inescapable". The information of the arrival of the virus in Nigeria and the construction of the inescapability of the footprints of the virus in Nigeria call on the leaders, health-workers and individuals to activate their roles in the different containment measures.

\section{Economic Cankerworm}

A canker(worm), viewed in the strict sense as a disease that destroys the woods of plants and trees, is also generally seen as an evil or dangerous influence that spreads and affects people's behaviour. The newspaper editorials converge to imply that COVID-19 is an economy canker that, if not immediately tackled, will throw the whole world beyond economic recession. The preponderant representation of COVID-19 as an economic canker takes $14 \%$ of the total representations. Texts 7-10 exemplify this representation. 
(7) Mr. Trump already has signed an $\$ 8.3$ billion spending bill focused on public health measures, but more is needed (NYT, March 12, 2020).

(8) "Using the word pandemic now does not fit the facts, but it may certainly cause fear", the WHO director general, Dr Tedros Adhanom Ghebreyesus, warned on Monday. As concern spreads, economic effects are growing alongside the human toll. Stock markets have taken a hammering. Airlines are suffering, major international events are being cancelled, and companies dependent on Chinese-made components have halted production (The Guardian, February 25, 2020).

(9) Since almost all major economies, ranging from the European Union to East Asia, and the United States, are battling the virus, and the infection rate is in an explosive growth stage in many of the countries, a global recession is becoming ever more likely as the virus spreads worldwide (China Daily, March 11, 2020).

(10) AS the country braces for the inevitable adverse economic impact of the raging coronavirus pandemic, the federal and monetary authorities, the legislature and the private sector have separately been rolling out a raft of measures to stave off catastrophe. ........Italy's $€ 3.5$ billion stimulus, France's $€ 45$ billion, Australia's A $\$ 17.6$ billion, South Korea's US\$9.8 billion and China's $\$ 270$ billion loan relief programmes are designed to provide immediate succour to the sick, maintain infrastructure, keep companies and wages afloat and support consumer spending. Efforts by Nigeria should aggregate these objectives (The Punch, March 31, 2020).

The editorials demonise COVID-19 by portraying the virus as an evil that is capable of throwing the world economy into mayhem. Since the state needs to fund the health facilities with huge sum while a running economy that could have kept running to cushion the depleting effect of the funding is at a standstill, this portends a grave danger to the world. Text 7 deploys Illustration discourse strategy to exemplify the huge amount " $\$ 8.3$ billion spending bill" that the US President has already released to fight the virus. The expression that suggests the insufficiency of the fund "but more is needed" implicates the virus as a canker (worm) that is eating into the fabrics of the world economy. The editor in text 8 also deploys example/illustration discourse strategy, lexicalisation and Negative otherpresentation to implicate the virus as economic cankerworm. The use of expressions such as "Stock markets have taken a hammering", "Airlines are suffering", "major international events are being cancelled", and "companies dependent on Chinese-made components have halted production" to lexicalise and appropriately illustrate how the supposed economy boosters are being grounded underscores the crumbling posture of the economy. Similar strategies are deployed in text 9 , while the editor concludes by pontificating that "a global recession is becoming ever more likely as the virus spreads worldwide", having cited the unprecedented dent the situation has recently had on "all major economies" across the world: "the European Union", "East Asia", and "the United States", all of who are combatting the virus, using all their economic strength with no immediate hope of recouping. Yet, the infection keeps growing and exploding in many other countries. In text 10 , the editorial portrays the virus using "inevitable adverse economic impact of the raging coronavirus pandemic." Hence, the inevitability of 
the portending effect of the economic adversity incriminates COVID-19 as a cankerworm already propelling the world economy into shambles.

\section{Threat to Humans}

The newspapers construct COVID-19 as threat - an expression of intention to inflict evil, injury, or damage - to humans. This representation (with $11 \%$ of the identified representations) is evident in texts 11-12.

(11) What has altered is the nature of the threat. Covid-19 is 50 times more deadly than swine flu. It is far more easily transmitted. The world is more globalised, heightening the risk of rapid spread of the virus, especially one that travels with close contact (The Guardian, March 31, 2020).

(12) Washington should look at what is happening in the US and realise that this is not a time for one-upmanship. Instead of trying to use the pandemic as a means to segregate China from the international community, it should embrace our shared identity as humans in the face of this common threat (China Daily, March 26, 2020).

The newspapers converge to paint COVID-19 as a threat to the existence of man, especially since it is capable of inflicting evil, injury, or damage. In texts 1112 , the editorials of the sampled papers deploy such discourse structures as actor description, lexicalisation, burden illustration, evidentiality and number game, to support the representation of COVID-19 as a threat to humanity. As a case in point, text 11 commences with Actor Description to talk about the nature of COVID-19, described as a threat in "What has altered is the nature of the threat. Covid-19 is 50 times more deadly than swine flu", deploying Number Game, spiced with call to action by the leaders to immediately do the needful to placate the evil virus. The demonisation of the virus as evil and its criminalisation instill the need for caution and vigilance in the mind of the citizenry to either cooperate with the government and health providers and or protect themselves from an impending global threat, since the virus is further given Actor Description as being "far more easily transmitted". The description further cautions travellers and implicates them as potentially more vulnerable thus: "The world is more globalised, heightening the risk of rapid spread of the virus, especially one that travels with close contact".

Text 12 implicates the virus as not just a threat, but a common threat to all humans. It commences by deploying the discourse structure "Burden" thus: "Washington should look at what is happening in the US and realise that this is not a time for one-upmanship" in order to canvass for oneness for humanity to defeat the common threat - the epidemic eruption that requires instant reprisal. China Daily ideologically negatively implicates the US government's show of arrogance and untimely segregation, implying that the US leadership was "trying to use the pandemic as a means to segregate China from the international community" since the COVID-19 had started wreaking havoc on the US. China Daily further deploys Norm Expression to categorically state what it expected of the US at a period like 
this - "it should embrace our shared identity as humans in the face of this common threat", castigating the virus as a common threat to all humanity.

\section{Warfare}

Warfare implies struggle between competing entities or an activity undertaken by a political unit (as a nation) to weaken or destroy another. The newspaper editorials perceive and describe COVID-19 as a war (with 10\% of the identified representations) to be fought, as evident in texts 13-15.

(13) Mr. Trump has proclaimed himself a "war president." Why, then, won't he rally Americans around this cause? Winning this war will require shared sacrifice, and tremendous short-term hardship for Americans. But failure would mean devastating loss of life and prolonged, widespread economic pain (NYT, March 24, 2020).

(14) Britain has finally declared war on Covid-19. Ministers say that the science left them no alternative but to fight. This was never a war of choice. The virus is no ordinary foe (The Guardian, March 17, 2020).

(15) The war against the virus is one we all have to fight together, the longer the pandemic persists the worse its effects will be (China Daily, March 26, 2020).

Texts 13-15 deploy different ideological discourse structures including Authority, Actor Description and Metaphor to represent COVID-19 as war or warfare. The expressions "Winning this war", "war on COVID-19" and "The war against the virus" in texts 13, 14, and 15 respectively, implicates and metaphorically presents COVID-19 as war, stating it is a battle to be fought and won by all. First, text 13 uses Authority to take recourse to the pronouncement of the US president, and uses Actor Description to describe him as a self-acclaimed "war president", capable of leading the war against COVID-19. The unveiled question, "Why, then, won't he rally Americans around this cause?" is a subtle condemnation strategy strategically positioned in the editorial to query the president's lethargy and indecisive pace in prosecuting the war. The last sentence presents the consequential projected effect on Americans should the president continue to delay in swinging to action. Similarly, text 14 subtly attacks the lateness of the leadership of Britain in going to war against COVID-19 as suggested by the word "finally". The text equally underscores the compulsion of the war, "This was never a war of choice". Text 15 advocates oneness in the battle "we all have to fight together," and expounds the need for urgency in the war thus: "the longer the pandemic persists the worse its effects will be". Hence, COVID-19 is a battle; it is a war that all nations must come together to fight earnestly.

\section{Killer (Disease)}

COVID-19 is represented as a killer - something that terminates or ends the life of another. Any potential killer is perceived as a criminal. The lexical item 
'kill' is used by the newspapers to represent COVID-19 as a killer (with 6\% of the identified representations) as exemplified in texts 16-18.

(16) Covid-19, the disease caused by this new virus, appears to be between seven and 20 times more deadly than seasonal flu, which on average kills between 300,000 and 650,000 people globally each year. But that fatality rate could prove to be much lower, especially if it turns out that many milder cases have evaded detection (NYT, February 29, 2020).

(17) The Guardian view on the Covid-19 strategy: insuring against a killer (The Guardian, March 31, 2020).

(18) However, while the world may have witnessed many wars and outbreaks of killer diseases, the Covid-19 has presented a challenge unlike any other before (The Punch, March 20, 2020).

The representation of anything or anyone as a killer implicates criminalisation and or demonisation. Texts 16-18 lexicalise, criminalise and demonise COVID-19 as a killer using lexical items such as "kill", "deadly", "fatality", and "killer". To underscore the representation of COVID-19 as a killer disease the discourse structures actor description, evidentiality, lexicalisation and burden are deployed. Texts 16 gives a further description of the virus, using evidential figures 300,000 650,000 of minimum potential victims of other COVID-19-related viruses as the basis for argument, thereby criminalising and demonising COVID-19 to emphasise that the earlier everyone is conscious of the potential evil of the virus the better. Meanwhile text 17 only warns all on the need to be insured "against a killer". Text 18 also activates the use of Burden and Comparison to argue that COVID-19 cannot be compared with other "outbreaks of killer diseases", and argue that all should consciously see COVID-19 as a "challenge unlike any other before." Hence, everyone needs to be conscious of the "killer".

\section{Plague}

The newspapers also represent COVID-19 as a plague (4\% representation). A plague is a disastrous evil or affliction or an epidemic disease causing a high rate of mortality, and has characterised COVID-19 already reported to have claimed numerous lives.

(19) We've been down this road before, too many times. In the $14^{\text {th }}$ century the Black Death provoked mass violence against Jews, Catalans, clerics and beggars; when syphilis spread in the $15^{\text {th }}$ century, it was called variously the Neapolitan, French, Polish and German disease, depending on who was pointing the blame; when the plague struck Honolulu in 1899, officials burned down Chinatown. And so on, down to our times, when epidemics like Ebola, SARS and Zika fueled animus toward specific regions or peoples. Here we are in 2020, with Asians being assailed across the United States and around the world as purported sources of the "Chinese flu", the "Wuhan coronavirus" or simply the "foreign virus". Once again, a mysterious, fast- 
spreading and sometimes lethal disease is exacerbating racism and hatred - only now with the help of the potent megaphone of social media. (NYT, March 23, 2020).

(20) Not much is known about COVID-19 as experts are still gathering information about the virus. All hands should be at the plough; apart from mobilising all health professionals like Lagos and many countries who have recalled retired care givers, student doctors and other volunteers, other states and the government should follow and mobilise all segments of the society to confront this plague (The Punch, March 24, 2020).

The representation of COVID-19 as a plague is very close to its representation as a pandemic or epidemic. However, the choice of the word "plague" resonates more with Christians or Bible scholars who are more conscious of the dastardly effect of a plague. This representation is therefore both informational and a plea for them to swing into action. The representation was only projected by NYT and The Punch newspapers. Text 19 commences with the use of historical reference as Burden, Evidentiality and Comparison to substantiate the argument and represent what similar plagues had done in the past, comparing them with COVID-19 and establishing the view that they share "plagueness" in common. Hence, COVID-19, as a "plague" that it is, is a "fast-spreading and sometimes lethal disease". Text 20 only makes reference to COVID-19 requesting all hands to be on the deck "to confront this plague".

\section{(Man's) Common Enemy}

An enemy is someone that is antagonistic to another or who seeks the other's injury. Enemy (3\%) representation has been used to describe COVID-19.

(21) Boris Johnson's declaration of war on an invisible, elusive and advancing foe was long overdue (The Guardian, March 24, 2020).

(22) The virus is a common foe (China Daily, March 18, 2020).

Only The Guardian and China Daily have used "enemy or foe" to refer to COVID-19. The portrayal of COVID-19 as a man's common enemy underscores the fact that COVID-19 is a cog in the wheel of man's progress. The use of "common" underlines the need for man to come together in unison to combat the virus that is seeking the injury or fall of all. Meanwhile, text 21 still uses a subtle reprimand to allege that the British Prime Minister, Boris Johnson should have declared the virus as an enemy earlier than has just been done.

Fire

Fire, which is a severe trial or ordeal, controls $2 \%$ of the total representations. COVID-19 is also represented as fire.

(23) Here Comes the Coronavirus Pandemic: Now, after many fire drills, the world may be facing a real fire (NYT, February 29, 2020). 
(24) There is still a chance that Covid-19 will prove to be more fire drill than actual fire (NYT, February 29, 2020).

The representation of COVID-19 as fire is only found in NYT. Using the discourse structure, Comparison, texts 19 and 20 compare between fire drill and a real fire or actual fire. In essence, COVID-19 is metaphorically represented as not just a fire but the real fire or actual fire that all need to be wary of. This representation of COVID-19 as a severe trial or ordeal demonises COVID-19 and calls all to action.

\section{Disaster}

Disaster - a sudden misfortune bringing great damage, loss, or destruction has been correlated with COVID-19 in the newspapers. The representation of COVID-19 as a disaster is one of the least (2\%) representations as exemplified in text 25 .

(25) For those already suffering from war and other disasters, the prospect of the worst is almost unthinkable (The Guardian, March 17, 2020).

Again, only The Guardian newspaper conceives COVID-19 as a disaster. To the editor, if the people and the government see COVID-19 as a disaster, they will be more cognizant of the need to deal with it headlong. Text 25 uses Comparison to canvass that the impending disaster of COVID-19 is worse compared with war and other disasters. The other disasters are small compared with the misfortune, damage and destruction that COVID-19 is set to unleash.

\section{Representations and Participants: Implications}

COVID-19 has been variously represented as outbreak, pandemic, economic cankerworm, threat to humans, war, killer, plague, common enemy, fire and disaster. Different intentions subsist for the various representations. The central motive behind the various representations is to cognitively task the readers and the masses in general about the potential evil of COVID-19. COVID-19 is embodied as a disease that: spreads suddenly; spreads over a whole country or the whole world; affects people's behaviour; inflicts evil, injury, or damage to humans; weakens or destroys humans; terminates the life of its victims; causes a high rate of mortality; seeks human's injury; burns to death; and brings great damage, loss, or destruction. These various representations converge to demonise and criminalise COVID-19. Therefore, this is an invitation to humans (discursively referred to as participants) to swing into action, assume different positions and roles to confront the "demon" and "criminal".

Three different types of participants therefore evolve from the discourse. The participants include the state/health professionals, non-carriers of COVID-19 and carriers of COVID-19. The representations put the state (government) and the health professionals in the position of authority to come together to solve the 
problem already created by the onset of the virus, while the carriers and noncarriers are expected to obey the directives given by the government as advised by the health practitioners and professionals.

The different representations given to COVID-19 in the newspapers have diverse physical and psychological implications and intentions. The representations have a converging appeal to the cognitive, affective and psycho-motor domains of participants, conveying the need for unanimity by the three participants for success to be ascertained. The various representations further underscores the need: to battle the pandemic earnestly; for all to be wary of their actions in order to contain and curtail the spread of the virus; that all should behold the looming disaster if there is no cooperation to clip the pandemic from truncating the economy; to tackle the disease before it tackles humans.

The state and health practitioners are represented as the major solvers of the virus, while the health practitioners are represented as the carers. The state is expected to lock down and enforce lockdown to contain the spread, provide hospitals and other equipment like ventilators to treat carriers, create isolation centres for carriers, provide stimulus or palliatives to cushion the effect on the citizens, and so forth. The state is also expected to collaborate with the health professionals to massively test citizens, treat carriers, trace contact and research on vaccine. The editorials consistently deploy ideological discourse structures like Authority, Burden, Evidentiality and Comparison to refer to countries that have made a remarkable progress based on harmonious confrontation of the virus, as evident in text 26.

(26) But there is no question that the W.H.O.'s approach works better. Every region that has managed to get a coronavirus outbreak under control has succeeded thanks to a combination of social distancing and aggressive efforts to test as many people as possible. South Korea, for example, has tested some 274,000 people since February. The United States has tested just 82,000, the vast majority of them in the past few weeks (NYT, March 24, 2020).

In text 26, NYT uses W.H.O. as the authority to support its position, using both Burden and Evidentiality to argue out its position and citing the experience with South Korea as a ground, example and Illustration for America and others to follow in a bit to combat the pandemic. While this is a sort of call to action to the state, it is equally a condemnation strategy to query their lethargic pace in following the working example of South Korea. This also suggests to (potential) carriers the need for self-guard.

(27) But it takes political decisiveness to lock down a city or area. And it takes doctors, nurses, sickbeds, testing kits, breathing machines, medical oxygen, plus large amounts of disinfectant, surgical masks, protective overalls and goggles each day, to give purpose to the lockdown (China Daily, March 26, 2020).

(28) Around the world, authorities are being forced to make difficult and complex decisions in this crisis. Mass quarantines of the kinds seen in Wuhan, China and Italy, may not be the only or even the best approach; it appears aggressive testing and contact tracing with some social distancing measures have been effective in countries 
including Singapore and South Korea (which has been testing 20,000 people a day) (The Guardian, March 12, 2020).

Texts 27 and 28 also suggest other roles expected of the state, including lockdown, contact tracing, aggressive testing of the citizens, citing the example of Wuhan, China as the approach which assisted in timely containment. Although the total or partial lockdown has its attendant negative consequence, including economic stagnancy, economic melt-down, occupational denial, hijack of jobs, denial of freedom, house arrest and so forth, it is better off for early containment on the long run. Text 29 also suggests that all the participant-roles will not really be as effective as discovering a vaccine that will ultimately help to solve the problem. Of course, this is a role expected of health professionals, which also relies on funding by the state.

(29) No matter how effective wearing face masks, washing hands, self-quarantining and social distancing are in preventing people from being infected with the novel coronavirus, a vaccine will ultimately be the most effective solution (China Daily, March 18, 2020).

The non-carriers are represented as potential victims and spreaders of COVID-19.The non-carriers, who are potential victims and spreaders, are expected to abide by the directives of the government and health practitioners. Hence, they are required to collaborate with the state in distancing socially (spatially); disinfecting surfaces around; maintaining healthy lifestyle by consuming healthy food, engaging in regular exercise and sleeping well; coughing or sneezing into bent elbow; disposing of used tissue; washing hands with soap \& running water; sanitising one's hands regularly; protecting self \& others against droplets; not touching mouth, nose, and eyes; wearing nose/protective mask; staying home/safe; not panicking and consuming immunity boosters, as evidently expressed in samples 30 and 31 .

(30) No matter how effective wearing face masks, washing hands, self-quarantining and social distancing are in preventing people from being infected with the novel coronavirus, a vaccine will ultimately be the most effective solution. That explains why President Xi Jinping emphasised the importance of science and technology in the fight against the virus in a signed article published in Qiushi Magazine on Monday (China Daily, March 18, 2020).

(31) Since coronavirus has no known cure, prevention remains the best form of defence. A highly contagious disease, people have been warned to stay away from crowded places and to avoid unnecessary contact. The United States Centres for Disease Control and Prevention says the best protection is to wash hands often with soap and water for at least 20 seconds. People have also been advised to keep a distance from sick people and to "avoid touching your eyes, nose or mouth with unwashed hands". When coughing, tissues should be used to cover one's mouth. It is expected that most people who suffer from coronavirus may eventually recover on their own; but the CDC advises that the symptoms should be treated. Those mildly 
sick are advised to drink a lot of liquid and observe adequate rest (The Punch, January 30, 2020).

The emphasis on social distancing has to do with a reduction in or totally stopping physical contacts with others. Socialisation has to do with societal or communal involvement of a people. It could also relate to interactants in a social sect. The editorials deploy ideological discourse structures like Authority to represent the virus as anti-social. The activation of social distancing among all humans as authorised by the WHO indexes COVID-19 as anti-socialisation, that is a breaker of socialisation. Although Abel and McQueen (2020) query the correctness and grammaticality of "social distancing", and suggest "spatial distancing" in its place, the concept of distancing is still of essence. Of course I agree with the stance of Abel and McQueen that we need to project more of spatial distancing than "social" since communication via the phone and other nonphysical means can still be termed "social". Even this discoursal incongruity has been further spread and projected by the W.H.O., represented in text 32 thus:

(32) The World Health Organization, for weeks now, has been making an emphatic plea to countries around the world: Social distancing is crucial to stopping the spread of coronavirus (NYT, March 19, 2020).

The actual carriers, whose cases may be mild or non-mild, are the real spreaders of COVID-19. While the mild carriers, also referred to as asymptomatic carriers, may not immediately display symptoms, the non-mild carriers display symptoms within the first and fourteenth day of having contact with a carrier or (super-)spreader.

(33) Symptoms, according to the World Health Organisation, include fever, cough, shortness of breath and breathing difficulties. In severe cases, it could lead to pneumonia, SARS, kidney failure and death (The Punch, January 30, 2020).

As spelt out in text 33 and others, and as authorised by the WHO, some of the symptoms of COVID-19 are itchy/dry throat, dry cough, high temperature, fever, fatigue, body aches, shortness of breath, loss of smell/taste, and so forth. Carriers are therefore expected to collaborate with the state to isolate from others, cooperate with carers, consume immunity boosters, and so forth.

\section{Conclusion}

This study on COVID-19 set out to examine selected newspaper editorials across four continents/countries in the world in order to identify how the virus and associated participants are represented in newspapers globally. The analysis was guided by aspects of van Dijk's (2006c) socio-cognitive model of critical discourse analysis on ideological discourse structures. The selected COVID-19-related editorials of newspapers (New York Times, The Guardian, China Daily and The Punch) which cut across the USA in North America, the UK in Europe, China in 
Asia and Nigeria in Africa were subjected to quantitative and discourse analyses. The newspapers largely set the agenda on the negative representation of the disease and its potential havoc on all facets of human endeavours, thereby giving emotional and informational appeal to all to join hands in earnestly silencing the epidemic.

The study revealed that the newspaper editorials unusually converged to negatively represent an issue - COVID-19 - because it is largely negatively viewed by all. The newspaper editorials variously represented COVID-19, using ten representational strategies: outbreak, pandemic, economic cankerworm, threat to humans, war, killer (disease), plague, common enemy, fire and disaster. Different intentions subsist for the various representations, just as differences are observed in the newspaper representations. All the newspapers converge to represent COVID-19 as outbreak, pandemic, economic cankerworm, threat to humans and war; whereas there were observed differences in the representations of COVID-19 as killer (disease), plague, common enemy, fire and disaster. The representation as plague was only projected by NYT and The Punch newspapers; the representation as man's common enemy was only used by The Guardian and China Daily; only NYT represented COVID-19 as fire; and only The Guardian newspaper conceives COVID-19 as a disaster.

The representational strategies were developed by the newspapers with six discourse strategies, including demonising the disease, criminalising the disease, calling the state to action, emotional and informational appeal to the masses, condemnation of the state, and historical reference. To the reader's cognition, therefore, the implication is that of consciousness on the evil effect of COVID-19 and the need to cooperate with the state and health workers to checkmate its evolution. Consequently, the represented human participants have different roles to play in safeguarding the globe. While the state and health professionals are represented as major problem-solvers and carers, the (non-)carriers are represented as (potential) victims and or (super) spreaders who must perform different containment roles, including social distancing (preferably, spatial/physical distancing); staying at home to stay safe from the virus; wearing a nose/mouth mask; keeping clean hands with soap and alcohol-based sanitizer regularly; sneezing or coughing into a flexed elbow or a disposable towel; avoiding touching of the face, especially mouth, eyes, and nose; avoiding touching surfaces, among others in order to collectively combat the virus. Both the COVID-19 and human representational strategies were also reinforced through the deployment of twelve ideological discourse structures: actor description, authority, burden, comparison, evidentiality, illustration, generalisation, lexicalisation, metaphor, negative otherpresentation, norm expression and number game.

Therefore, this paper argues that the reporters and the newspapers, whose mental models have already been formed by the implicit and explicit information on COVID-19, establish the agenda by positioning their readers' cognition to negatively perceive coronavirus (COVID-19). The ten representations give adherence to the agenda-setting prowess of the media. The negative portrayal, demonising and criminalising COVID-19, alongside other constructions, as identified with the discourse tools, goes a long way in creating a cognitive 
awareness in the minds of the citizenry, bringing consciousness to the readers on the negative capability and destructive strength of the life-threatening disease.

\section{References}

Abel, T., McQueen, D. (2020). Editorial: the COVID-19 pandemic calls for spatial distancing and social closeness: not for social distancing! International Journal of Public Health, 65(3), 231.

Baehr, P. (2006). Susan Sontag, battle language and the Hong Kong SARS outbreak of 2003. Economy and Society 35(1), 42-64.

Barry, J. H. (2005). 1918 Revisited: lessons and suggestions for further inquiry. In S. L. Knobler et al. (eds.), The Threat of Pandemic Influenza: Are We Ready? 58-68. Washington DC: National Academies Press.

Chen, S. (2005). Whence Cometh SARS: a short description of a pattern of inter-cultural contacts and related discourses in Taiwan. In Proceedings of the $8^{\text {th }}$ 1ASS Congress IASS and Univ-Lyon, 1-9.

Chiang, W., Duann, R. (2007). Conceptual metaphors for SARS: 'war' between whom? Discourse \& Society, 18(5), 579-602.

Chiluwa, I., Odebunmi, A. (2016). On terrorist attacks in Nigeria: stance and engagement in conversations on Nairaland. Communication and the Public, 1(1), 91-109.

Eagleton, J. (2004). SARS: "It's as bad as we feared but dared not say". English Today, 20(1), 34-45.

Fairclough, N. (1995). Critical discourse analysis: the critical study of language. London: Longman.

Larson, B. M. H., Nerlich, B., Wallis, P. (2005). Metaphors and biorisks: the war on infectious diseases and invasive species. Science Communication, 26(3), 243-268.

Mahdi, Y. (2009). A critical discourse analysis of selected Iranian and American printed media on the representation of the Hizbullah-Isreal war. Retrieved from: http://www. immi.se/intercultural/. [Accessed 24 January 2014]

Majid, K. (2008). British newspapers and the representation of refugees, asylum seekers and immigrants between 1996 and 2006.Working Paper Series: Centre for Learning and Social Life, 128(3), 44-62.

Osisanwo, A. A. (2011). Language and ideology in news magazine's representation of Nigeria's 2003 and 2007 general elections. PhD Thesis. Ibadan, Nigeria: Department of English, University of Ibadan.

Osisanwo, A. A. (2016a). Discursive representation of Boko Haram terrorism in selected Nigerian newspapers. Discourse and Communication, 10(4), 341-362.

Osisanwo, A. A. (2016b). Role allocation in the media representation of participants in selected electoral discourses in Nigeria. Athens Journal of Mass Media and Communications, 2(3), 183-204.

Osisanwo, A. A. (2017a). Linguistic features of news reports of war on terrorism in Nigeria. Ife Studies in English Linguistics, 13(2), 57-82.

Osisanwo, A. A. (2017b). Stance and engagement in e-punch newspaper readers' comments on former President Goodluck Jonathan administration's war against Boko Haram terrorism in Nigeria. Journal of English Studies Association of Nigeria, 19(1), $143-160$.

Osisanwo, A. A. (2019). Blame-frame and praise-frame on the Boko Haram terrorism in Nigeria newspapers: a discourse examination. PEOPLE: International Journal of Social Sciences, 4(3), 1633-1651. 
Osisanwo, A. A., Oluwayemi, V. (2018). Divorce as conflict: representation of participants in selected Nigerian newspaper reports on divorce cases. Ibadan Journal of Humanistic Studies, 28(1): 91-108.

Oyeleye, L., Osisanwo, A. A. (2013a). Lexicalisation in media representation of the 2003 and 2007 general elections in Nigeria. World Journal of English Language, 3(2), 1-9.

Oyeleye, L., Osisanwo, A. A. (2013b). Expression of ideologies in the media representation of the 2003 and 2007 general elections in Nigeria. Discourse \& Society, 24(6), 763773.

Potter, C. W. (2001). A History of Influenza. Journal of Applied Microbiology, 91(4), 572-579.

Talaat, P. (2011). Islamists in the headlines: critical discourse analysis of the representation of the muslim brotherhood in Egyptian newspapers. PhD Thesis. Utah, USA: Department of languages and literature. Arts, University of Utah.

Trčková, D. (2015). Representations of natural catastrophes in newspaper discourse. Brno: Masaryk University.

van Dijk, T. (2001a). Discourse, ideology and context. Folia Linguistica, XXXV(1-2), 1140.

van Dijk, T. (2001b). Multidisciplinary CDA: a plea for diversity. In R. Wodak, M. Meyer (eds.), Methods of Critical Discourse Analysis, 95-120. London: Sage Publications.

van Dijk, T. (2006a). Introduction: discourse, interaction and cognition. Discourse Studies, $8(1), 5-7$.

van Dijk, T. (2006b). Discourse and manipulation. Discourse \& Society, 17(2), 359-383.

van Dijk, T.A. (2006c). Politics, ideology and discourse. Barcelona: Elsevier Services.

Wallis, P., Nerlich, B. (2005). Disease metaphors in new epidemics: the UK media framing of the 2003 SARS epidemic. Social Science and Medicine, 60(11), 2629-2639.

Washer, P. (2004). Representations of SARS in the British newspapers. Social Science \& Medicine, 59(12), 2561-2571.

Wodak, R. (2002). Aspect of critical discourse analysis. ZFAL 36, 5-31. 